\title{
Standpunt
}

\section{Natuurwetenskaplike opleiding voor groot uitdagings}

In hierdie dae van hersicning van onderwysprogramme word woorde soos "bemagtiging" en "uitkomsgebaseerd" dikwels gehoor. Dit laat'n mens weer opnuut vra na die aard van kennis, veral in die natuurwetenskappe. Is kennis 'n hoop feite wat die student eenvoudig moet indrink, opslurp en bemeester, of is dit 'Il gedurig veranderende stroom van konsepte waarby die student dwarsdeur sy lewe telkens moel aanpas?

Wat moet 'n student bemeester - feite of probleemoplossende vaardighede? Indien 'n mens na die sillabusse van verskeic vakke in die naluurwetenskappe kyk, blyk daar tog in sommige rigtings ' $n$ wanbalans lussen hierdie twee uiterstes te wees. Die eise wat die verskillende beroepsvelde in die naluurwetenskappe stel, is uiteraard uiteenlopend. Nogtans wil dit voorkom asol die tocrusting van byvoorbeeld natuurwetenskaplike navorsers vir hulle latere lewenstaak gebrekkig is as gevolg van die swaar beklemtoning van parate, gememoriseerde, tydelik relevante feitckennis.

In veral sommige dissiplines word studente met die lepel gevoer en moet hulle berge inligting absorbeer wat met tussenposes in eksamens uitgestal word. Dit is ook waaraan die student se "standaard" soms gemeet word.

In dié tye waar vrese ook uitgespreek word dat standaarde in gedrang sal kom, is dit dus nodig om noulettend na hierdic "standaarde" te kyk. Dit is my ervaring dat studente met gocie geheues wat hardwerkend memoriseer, in sekere dissiplines uitstekend "presteer" en dus 'n hoe "standalard" daarstel. Ilicrdic studente, so leer dic ervaring ook, is meestal waarnemers van kennis en gebruik nie noodwendig daardie kennis op een of ander konstrukliewe wyse nic. 'n Proses soos hierdie watardeur "prestecrders" beloon word vir ensiklopediese kennis kan sonder twyfel lei tot'n valse gevoel van wysheid.

Ons is tans besig om die ceu van inligting te betree weens die groot spronge wat dic inligtingstegnologie in die jongste jare gegee het. Inligting is nou meer vrylik beskikbalar en toeganklik as ooit te vore, selfs in verwerkte vorm. Dic universiteitsdosent wat nog meen dat dit sy primêre taak is om inligting oor te dra, sal agterkom dat die mededinging só sterk geword het dat hy eersdaags geen studente meer in sy klas sal hê nic. Dic inligting wat hy bloot oordra, sal tuis ook op die wêreldwye web (www) beskikbaar wees.

Aan die ander kant sal studente wal toegerus is mel die basiese beginsels en reêls van inligtingsontsluiting, in staal wees om die steeds sterker vlociende stroom van inligting en nuwe gegewens aan te durf. Hulle sal die relevante inligting van die opdrifsels kan onderskei.

In bykans alle beroepsvelde sal mense die beskikbare informasietegnologic moet kan gebruik om dic relevante inligting op te spoor en in 'n persoonlike maar voortdurend veranderende denkraamwerk te integreer. Is kennis dus nou die stroom van inligting walaruit eenmalig gedrink word of dic vermoë om dic regte inligting voortdurend uit dic stroom op te vang en to gebruik?

Die behoefte aan die integrering van inligting uit verskillende strome en die ontwikkeling van bruikbare konsepte is groter as wat aldag besef word indien 'n land op die wêreldmarkte wil meeding. Die mense wat oor hierdie vermoëns beskik, sal meer as ooit te vore 'n multidissiplinêre agtergrond moet hê. Dit is juis diegene wat breed genoeg onderlê is en insig het in die beginsels van verskeic dissiplines, wat probleme ten volle sal begryp en mel bruikbare oplossings sal kan kom. Dié natuurwetenskaplike lakulteite aan universiteite en technikons se lake van onderrig en navorsing word in werklikheid enersyds makliker gemaak deur die groter toeganklikheid tot en beskikbaarheid van inligting. Nou kan hulle meer op die konseptuele en prinsipiele aspekte konsentreer.

Dié individuele dosent wat tot nou toe sy/haar posisie op grond van ensiklopediese kemnis probeer handhal het, sal seker nic saimstem nic en dalk 'n bedreiging ervaar.

Dic uildaging vir akademiese inrigtings is om die relevansic en aanbiedingswyse van hulle sillabusse opnuut te bekyk en to evalueer in terme van onder andere etiese verantwoording, uilkoms en aanwending van verworwe kundigheid. Word studente inderdaad beide verryk en bemagtig?

Daar is reeds stemme wat opgatan dat ons ons lesingsale moet omskep in aktiewe laboratoriums van deelnemende leer walar die ernstige probleme van voedseltekorte, ongewings besoedeling, ens. mel erns aangepak word. Probleemgedrewe onderrig dus. Die gedagte is dat 'n mens makliker leer as dic leerervaring gerig is op die oplossing van werklike probleme. En alle groot probleme vra' 'n multidissiplinere benadering deur 'n span kundiges en lerendes wat saam kopkrap.

Opvoedkundiges sal waarsku dat dit gevaarlik is om 'n proses aan die gang te sit waarvan die uitkoms onseker is. Waar ons egter redelik seker is van die beoogde uitkoms en die praktiese uitvoerbaarheid, moet ons nie huiwer om die tradisionele klaskamerlesing vir 'n meer interaktiewe, probleemgerigte spanpoging te verruil nic.

Ons staan voor interessante uitdagings.

Indien ons natuurwetenskaplike opleiding so kan vernuwe dat ons sonder verlies van gehalte meer en beter studente kan trek, sal die natuurwetenskaplikes hulle regmatige bydrac to die ontwikkeling van Suid-Alrika kan lewer. Die innoverende benutting van nuwe tegnologieë maak dit moontlik.

A.J. REINECKE Departement Soölogie, Universiteit van Stellenbosch 